\title{
PENGARUH RASIO TEPUNG BERAS MERAH(Oryza Nivara L) DAN KACANG HIJAU (Phaseolus Radiatus L) PADA PRODUK SNACK BAR TERHADAP KANDUNGAN PROTEIN DAN DAYA TERIMA OLEH ANAK USIA SEKOLAH
}

\author{
Anita Rahayu ${ }^{1}$, Irwan Haryanto ${ }^{2 *}$, Ardhika Ulfah ${ }^{3}$ \\ 1,2,3 Sekolah Tinggi Ilmu Kesehatan Holistik \\ *Korespondensi: Jl. Veteran No, 272 Ciseureuh, Purwakarta, Email: irwanhyt@yahoo.com
}

\begin{abstract}
ABSTRAK
Latar Belakang: Anak usia sekolah rentan mengalami kekurangan zat gizi. Proporsi anak usia sekolah yang defisit energi secara nasional 83,9\%, sebanyak 64,4\% defisit energi tergolong berat $(<70 \%$ AKE) dan defisit protein sebesar $17,8 \%$ tergolong berat $(<70 \% \mathrm{AKP})$. kekurangan energi dan protein pada anak akan berpengaruh terhadap konsentrasi belajar menurun, imunitas tubuh menurun, dan pertumbuhan tidak optimal. Salah upaya yang dapat dilakukan untuk memenuhi kebutuhan energi dan protein anak usia sekolah yaitu dengan memberikan snack sehat yang dapat memenuhi kebutuhan protein anak usia sekolah salah satunya adalah snack bar tepung beras meras merah

dan kacang hijau

Tujuan Penelitian: Menganalisa daya terima dan kandungan protein snack bar tepung beras merah dan kacang hijau

Metode: Penelitian eksperimental menggunakan rancangan acak lengkap (RAL) dengan satu faktor yaitu perbandingan rasio tepung beras merah dan kacang hijau dan 3 kali pengulangan. Penelitian terdiri dari pembuatan kacang hijau kering, pembuatan snack bar, analisis kandungan protein dengan metode kejdahl, uji daya terima dengan uji skala kesukaan, penentuan formula terpilih dan kontribusi protein terhadap AKG pada anak usia sekolah. Panelis sebanyak 60 orang dari siswa Sekolah Negeri Karangmukti. Analisis statistik dengan menggunakan uji kruskal wallist test dan one way anova.

Hasil:Tidak terdapat pengaruh rasio tepung beras merah dan kacang hijau terhadap aroma $(p=0,473)$, rasa $(p=0,725)$ dan tekstur $(\mathrm{p}=0,335)$ snack bar, tetapi terdapat pengaruh pada warna snack bar $(p=0,004)$. Terdapat pengaruh rasio tepung beras merah dan kacang hijau terhadap kandungan protein snack bar $(p=0,00)$.

Simpulan: Perbedaan rasio tepung beras merah dan kacang hijau tidak berpengaruh terhadap daya terima aroma, rasa, tekstur dan terdapat pengaruh terdapat perbedaan rasio tepung beras merah dan kacang hijau terhadap kandungan protein snack bar. Namun ada pengaruh pada parameter warna.
\end{abstract}

Kata kunci: beras merah, daya terima, kacang hijau, protein, snack bar

\section{ABSTRACT}

Background: School-age children are vulnerable to nutrient deficiencies. The proportion of school-age children with an energy deficit of $83.9 \%, 64.4 \%$ of energy classified as heavy $(<70 \%$ $A K E)$ and protein deficit of $17.8 \%$ are classified as severe ( $<70 \%$ of PPA). lack of energy and protein in children will increase the increase in learning, increased body immunity, and growth is not optimal. One effort that can be done to meet the energy and protein needs of school-age children is by providing healthy snacks that can meet the protein needs of school-age children, one of which is a snack bar, red rice, rice flour, and green beans.

Objective: To analyze the acceptability and protein content of snack bars, red rice flour and green beans

Method: An experimental study using a completely randomized design with one factor, namely the ratio of the ratio of red rice flour and green beans and 3 repetitions. The research consisted of making dried green beans, making snack bars, analyzing protein content using the kejdahl method, accepting tests with a preference scale test, determining the chosen formula and protein 
contribution to RDA in school-age children. There were 60 panelists from Karangmukti Elementary School students. Statistical analysis using Crucial Wallist Test and One Way ANOVA.

Results: There was no effect of the ratio of brown rice flour and green beans to the aroma ( $p=$ $0,473)$, taste $(p=0.725)$ and texture $(p=0.335)$ snack bar, but there was an influence on the color of the snack bar $(p=0.004)$. There is an effect of the ratio of brown rice flour and green beans to the protein content of snack bars $(p=0.00)$.

Conclusion: the difference in the ratio of red rice flour and green beans does not affect the acceptability of aroma, taste, texture and there is an effect there is a difference in the ratio of red rice flour and green beans to the protein content of snack bars. But there is an influence on the color parameters.

Keywords: Acceptability, brown rice, green beans, protein, snack bar

\section{PENDAHULUAN}

Gizi merupakan salah satu faktor penting yang menentukan tingkat kesehatan dan keserasian antara perkembangan fisik dan mental. Dalam masa tumbuh kembang anak, kecukupan gizi merupakan hal mutlak yang harus selalu diperhatikan orang tua. Gizi yang baik merupakan pondasi bagi kesehatan masyarakat, jika terjadi masalah gizi, baik gizi kurang maupun gizi lebih pertumbuhan tidak akan berjalan dengan optimal 1 .

Kelompok usia yang rentan terhadap kekurangan zat gizi adalah pada kelompok anak usia sekolah. Penyebab langsung gizi kurang pada anak usia sekolah yaitu tidak tidak tercukupinya asupan makanan yang diperlukan oleh tubuh. Hasil Riskesdas tahun $2018^{2}$ menunjukan presentase gizi kurang berdasarkan IMT/U anak usia 5-12 tahun sebesar 9,2\%. Asupan energi dan protein anak sekolah sebagian besar termasuk dalam kategori kurang3. Proporsi anak usia sekolah yang defisit energi secara nasional 83,9\%, sebanyak 64,4 \% dan defisit protein sebesar $17,8 \%$.

kekurangan energi dan protein akan berpengaruh terhadap konsentrasi belajar anak menjadi menurun, imunitas tubuh, dan pertumbuhan tidak optimal. Adapun fungsi protein yaitu untuk pertumbuhan, anti body, membangun dan memelihara otot serta transfortasi oksigen ke seluruh jaringan tubuh ${ }^{4}$. Masalah gizi yang terjadi pada anak usia sekolah dapat mempengaruhi prestasi belajar anak yang akan berdampak pada menurunnya kualitas sumber daya manusia ${ }^{5}$.

Salah satu upaya yang dapat dilakukan untuk memenuhi kebutuhan energi dan protein anak usia sekolah yaitu dengan memberikan snack sehat yang dapat memenuhi kebutuhan protein anak usia sekolah. Salah satu snack yang banyak dikembangkan saat ini adalah snack bar ${ }^{6}$. Snackbar adalah pangan padat yang berbentuk batang dan merupakan campuran dari berbagai bahan kering seperti sereal, kacang-kacangan, buahbuahan kering yang digabungkan menjadi satu dengan bantuan binder. Binder dalam bar dapat berupa sirup, nougat, karamel, coklat, dan lain-lain 7 .

Dalam penelitian ini dibuat snack bar berbasis tepung beras merah dan kacang hijau. Pemanfaatan beras merah dalam bidang pangan masih kalah dibandingkan beras putih. Salah satu bentuk olahan beras merah paling sederhana adalah pembuatan tepung beras merah. Kandungan gizi yang terdapat dalam $100 \mathrm{~g}$ tepung beras merah yaitu 352 kalori energi, 9,16 gram protein, 0.9 gram lemak, dan 76.2 gram karbohidrat $^{8}$. Sedangkan kandungan gizi yang terdapat dalam 100 gram kacang hijau yaitu 323 kalori energi, 22.9 gram protein, 1.5 gram lemak, dan 56.8 gram karbohidrat ${ }^{8}$.

Penelitian ini bertujuan untuk mengetahui pengaruh rasio tepung beras merah dan kacang hijau terhadap daya terima dan kandungan protein pada snack bar tepung beras merah dan kacang hijau.

\section{METODE PENELITIAN}

Penelitian ini menggunakan rancangan acak lengkap (RAL) dengan tiga perlakuan dan tiga kali pengulangan. Perlakuan yang digunakan dalam penelitian ini yaitu perbandingan rasio tepung beras merah 
dan kacang hijau. Perbandingan rasio tepung beras merah dan kacang hijau yang digunkan adalah 60:40, 50:50, 60:40. Penelitian ini terdiri dari enam tahap, yaitu pembuatan kacang hijau kering, pembuatan snack bar, uji kandungan protein, uji daya terima, penentuan formula terpilih dan perhitungan sumbangan protein snack bar tepung beras merah dan kacang hijau terhadap \% angka kecukupan gizi (AKG) pada anak usia sekolah.

Uji daya terima snack bar tepung beras merah dan kacang hijau dilakukan di SDN

\section{HASIL}

\section{Daya terima}

Parameter warna diperoleh rerata skor F1

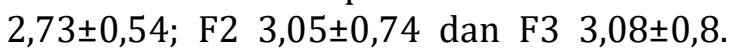
Dengan $\mathrm{P}$ value $<0,05$, maka dapat disimpulkan bahwa terdapat pengaruh rasio tepung beras merah dan kacang hijau terhadap parameter warna pada antar formula. Kemudian di uji lanjut dengan analisis Mann-Whitney untuk melihat perbedaan pada antar formulasinya.
Karangmukti, bungursari purwakarta dengan panelis sebanyak 60 orang terdiri dari kelas 4 sampai kelas 6 SD masingmasing kelas 20 orang dengan range umur 9 - 12 tahun. Sedangkan analisis kandungan protein dilakukan di Laboratorium Teknologi Pangan Universitas Pasundan Bandung. Hasil uji daya terima dianalisis menggunakan metode Kruskal Wallis Test dan hasil uji kandungan protein dianalisis dengan metode One Way ANOVA dan dilanjutkan dengan uji Duncan.

Didapatkan hasil signifikansi F1 dengan F2 $0,02(<0,05), \mathrm{F} 1$ dengan F3 0,05( $>0,05)$ dan F2 dengan F3 $0,76(>0,05)$. F1 memiliki warna coklat yang agak terang dibandingkan F2 dan F3, sehingga F1 dengan rasio tepung beras merah dan kacang hijau 40g;60g mendapat penilaian yang berbeda dari panelis terhadap parameter warna. Hasil rerata uji daya terima dapat dilihat pada Gambar 1.

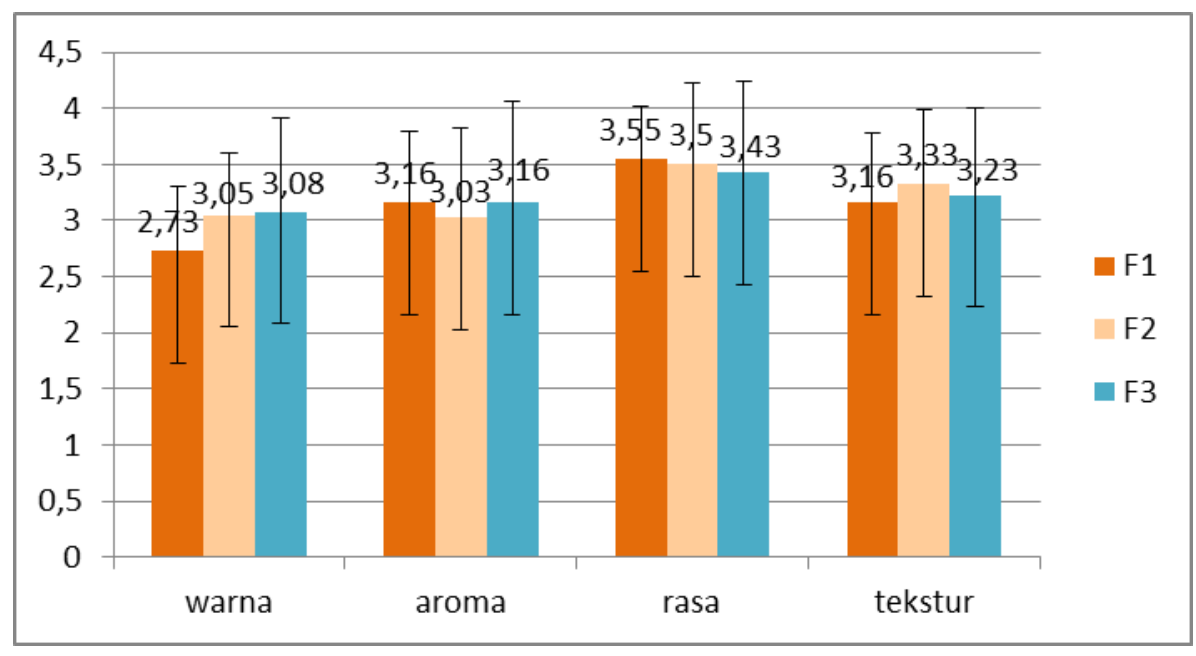

Gambar 1. Hasil Uji Daya Terima Snack Bar Tepung Beras Merah Dan Kacang Hijau

Keterangan: $p$ value $<0,05$ terdapat pengaruh, $>0,0,5$ tidak terdapat pengaruh rasio tepung beras merah dan kacang hijau. P value warna 0,004 , aroma 0,473 , rasa 0,725 dan tekstur 0,335

Parameter aroma didapat rerata skor F1 $3.17 \pm 0.64, \quad F 2 \quad 3.03 \pm 0.80$ dan F3 $3.17 \pm 0.90$ dengan $\mathrm{P}$ value $0.473(>0.05)$ maka tidak ada pengaruh rasio tepung beras merah dan kacang hijau terhadaparoma sncak bar. Parameter rasa didapatkan rerata skor F1 $3.5 \pm 0.75$, F2
$3.50 \pm 7.26$ dan F3 3.43 \pm 0.81 dengan P value 0.725 (>0.05) maka tidak ada pengaruh rasio tepung beras merah dan kacang hijau terhadap rasa sncak bar. Parameter tekstur didapatkan rerata skor $\mathrm{F} 13.17 \pm 0.61, \mathrm{~F} 2$ $3.33 \pm 6.55$ dan F3 3.23 \pm 0.77 dengan P value 0.335 (>0.005), maka dapat disimpulkan 
tidak ada pengaruh rasio tepung beras merah dan kacang hijau terhadap tekstur snack bar.

\section{Uji Analisis Kandungan Protein}

Hasil analisis kandungan protein snack bar di uji dengan analisis One Way Anova kemudian di uji lanjut dengan Duncan. Berdasakan gambar 2 dan table 2 didapat hasil rerata pada F1 3.72 $\pm 0.10 \mathrm{~F} 2$
$3.90 \pm 0.07$ dan F3 3.88 \pm 0.56 dengan P value $0,000 \quad(<0,05)$ maka terdapat perbedaan kandungan protein dari ketiga formula tersebut, kemudian dilanjutkan dengan uji Duncan dan didapatkan hasil F1, F2 dan F3 berbeda signifikan. Hasil analisis kandungan protein snack bar dapat dilihat pada Gambar 2.

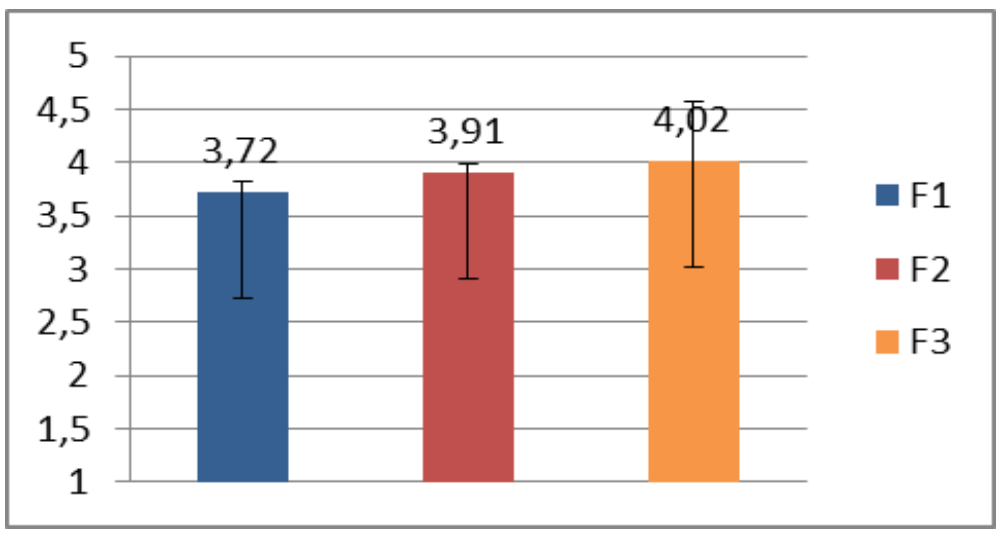

Gambar 2 Hasil Analisis Kadar Protein Snack Bar

Keterangan: $p$ value $0,00<0,05$ terdapat pengaruh rasio tepung beras merah dan kacang hiaju terhadap kandungan protein snack bar

\section{Penentuan Formula Terpilih}

Formula terpilih merupakan formula dengan jumlah skor terbesar. Berdasarkan table 2 formula dengan skor terbesar didapat pada formula 3 dengan nilai 3,69. Dan nilai terkecil didapat oleh F1 3,498 . Jadi dapat disimpulkan bahwa formula terpilih didapat oleh F3 dengan perbandingan rasio tepung beras merah dan kacang hijau 60g:40g.

Hasil penentuan formula terpilih berdasarkan hasil uji daya terima dan uji kandungan protein dapat dilihat pada table 1.

Tabel 1. Skor Penentuan Formula Terpilih

\begin{tabular}{cccc}
\hline Formula* $^{*}$ & $\begin{array}{c}\text { Uji kesukaan } \\
\mathbf{( 4 0 \% )}\end{array}$ & $\begin{array}{c}\text { Kadar Protein } \\
\mathbf{( 6 0 \% )}\end{array}$ & $\begin{array}{c}\text { Skor } \\
\mathbf{( 1 0 0 \% )}\end{array}$ \\
\hline F1 & $1,268(3)$ & $2,23(3)$ & 3,498 \\
F2 & $1,292(1)$ & $2,34(2)$ & 3,632 \\
F3 & $1,278(2)$ & $2,41(1)$ & 3,69 \\
\hline
\end{tabular}

*Perbandingan rasio tepung beras merah dan kacang hijau 40:60 untuk F1, 50:50 untuk F2 dan 60:40 untuk F3.

\section{Sumbangan Kandungan Protein Snack Bar Terhadap Angka Kecukupan Gizi (AKG) Anak Usia Sekolah}

Sumbangan snack atau makanan selingan untuk kebutuhan energi harian sebesar $10-15 \%$ dari total kebutuhan energi perhari. Takaran saji snack bar dengan berat $50 \mathrm{~g}$ per takaran saji memberikan sumbangan energi $12 \%$ pada anak usia 7-9 tahun, tetapi untuk anak laki-laki 10-12 tahun memberikan sumbangan energi 9,9\% dan untuk anak wanita usia 10-12 tahun memberikan sumbangan energi 10,4\%, sehingga dapat disimpulkan bahwa snack 
bar dapat memenuhi energi untuk makanan selingan sebesar 10\%. Sedangkan untuk acuan label gizi suatu produk di klaim sumber protein harus memenuhi 20\% ALG dalam 100g snack bar. Hasil menunjukan protein snack bar dalam 100g hanya 13.3\%, maka dapat disimpulkan bahwa snack bar belum dapat di klaim sebagai sumber protein. Untuk memenhui kebutuhan AKG, dalam sehari snack bar dapat dikonsumsi 3 takaran saji.

Tabel 2 Kandungan Zat Gizi Snack Bar Pertakaran Saji dan Sumbangan

Kandungan Protein Pada Snack Bar Terhadap \%AKG Serta \%ALG

\begin{tabular}{|c|c|c|c|c|c|c|c|c|}
\hline \multirow[b]{2}{*}{ Komposisi } & \multirow{2}{*}{$\begin{array}{c}\text { Kandunga } \\
\text { n gizi } \\
(50 g)\end{array}$} & \multicolumn{3}{|c|}{$\begin{array}{c}\text { AKG Anak Usia 7-12 } \\
\text { tahun }\end{array}$} & \multicolumn{3}{|c|}{$\begin{array}{c}\text { \%Sumbangan AKG Anak } \\
\text { Usia 7-12 tahun }\end{array}$} & \multirow[b]{2}{*}{$\begin{array}{l}\text { \%ALG } \\
(100 \mathrm{~g})\end{array}$} \\
\hline & & $\begin{array}{c}7-9 \\
\text { tahun }\end{array}$ & $\begin{array}{c}10-12 \\
\text { tahun } \\
\text { (L) }\end{array}$ & $\begin{array}{c}10-12 \\
\text { tahun } \\
(P)\end{array}$ & $\begin{array}{c}\text { 7-9 } \\
\text { Tahun }\end{array}$ & $\begin{array}{c}10-12 \\
\text { tahun } \\
\text { (L) }\end{array}$ & $\begin{array}{c}10-12 \\
\text { tahun } \\
(P)\end{array}$ & \\
\hline Energi (Kcal) & 198,3 & 1650 & 2000 & 1900 & 12 & 9,9 & 10,4 & 18,4 \\
\hline Protein (g) & 4 & 40 & 50 & 55 & 10 & 8 & 7,3 & 13,3 \\
\hline Lemak (g) & 9,05 & 55 & 65 & 65 & 16,4 & 13,9 & 13,9 & 27 \\
\hline $\begin{array}{l}\text { Karbohidrat } \\
\text { (g) }\end{array}$ & 25,2 & 250 & 300 & 280 & 10 & 8,4 & 9 & 15,5 \\
\hline
\end{tabular}

\section{PEMBAHASAN}

Warna coklat pada snack bar ditimbulkan oleh penambahan coklat blok sebanyak $10 \mathrm{~g}$ disetiap formulasinya, sehingga warna yang muncul dominan warna coklat. Kemudian warna juga dipengaruhi proses pemanasan, proses pemanasan terjadi reaksi karamelisasi dari gula.. Selain itu reaksi maillard yang terjadi pada proses pemanggangan juga mengakibatkan warna coklat pada snack bar. Sehingga terdapat perbedaan penerimaan panelis pada parameter warna terhadap F1 dengan warna snack bar coklat kekuningan, sedangkan untuk F2 dan F3 warna nya hampir mirip yaitu coklat pekat. Berdasarkan hasil uji daya terima panelis lebih menyukai warna snack bar dengan warna coklat pekat karena identik dengan makanan coklat yang disukai anak-anak. Aroma yang dihasilkan oleh formula snack bar adalah aroma margarin dan aroma kacang hijau. Pada proses pemanggangan, aroma yang dihasilkan ditentukan oleh campuran kandungan lemak, asam amino, dan gula pada makanan. Kombinasi margarin sebagai lemak, kandungan asam amino pada bahan dasar yaitu kacang hijau yang dapat mengurangi aroma langu pada snack bar, serta madu yang memberikan aroma khas yang dihasilkan oleh snack bar setelah proses pemanggangan ${ }^{9}$.

Snack bar memiliki rasa yang manis. Namun rasa manis dari snack bar kurang dominan. Hal ini dikarenakan rasa manis dihasilkan oleh bahan tambahan dari snack bar yaitu madu, gula dan coklat. Semakin banyak penambahan tepung beras merah dapat menurunkan tingkat kesukaan panelis terhadap parameter rasa ${ }^{10}$. Hal tersebut dikarenakan tepung beras merah memiliki rasa yang khas, namun rasa khas tersebut dapat ditutupi oleh kacang hijau kering dan bahan tambahan seperti madu dan coklat, serta margarin, sehingga rasa snack bar relatif sama.

Tekstur bahan pangan sangat ditentukan oleh kadar air, kandungan lemak, dan jumlah serta jenis karbohidrat dan protein yang menyusunnya ${ }^{11}$. Selain itu tekstur snack bar juga dipengaruhi oleh protein yang terkandung dalam telur, dimana penambahan satu butir telur pada tiap formulasi sehingga tekstur snack bar pada F1, F2 dan F3 hampir sama. Selama proses pengadonan, gelembung udara terjebak dalam adonan yang disebabkan adanya albumin dari telur, saat proses pemanggangan, gelembung udara membesar dan selanjutnya protein dari putih telur mengalami koagulasi sehingga memberikan struktur busa yang permanen di dalam produk snack bar ${ }^{12}$. Hal ini disebutkan pula oleh Purnomo dkk ${ }^{13}$ (2005) bahwa pada pemanasan protein tidak lagi terbentuk sebagai koloid melainkan mengalami koagulasi dan bila ikatan antar gugus reaktif protein menahan cairan, maka akan terbentuk gel, sehingga terbentuklah keempukan pada tekstur makanan. 
Hasil analisis kandungan protein snack bar lebih rendah dari hitungan perkiraan berdasarkan TKPI. Hal ini mungkin terjadi karena snack bar sudah mengalami beberapa tahap proses pengolahan, seperti perendaman, perebusan dan pemanggangan. Proses pemanasan menyebabkan kerusakan protein dan terjadilah penurunan kandungan protein. Penurunan kandungan protein pada proses pemanggangan dengan suhu $100^{\circ} \mathrm{C}-180^{\circ} \mathrm{C}$ berkisar antara $3,73 \%$ sampai $5,24 \% 14$. Terdapat perbedaan kandungan protein pada tiap formulasi, hal ini mungkin dikarenakan ada perbedaan antara rasio tepung beras merah dan kacang hijau. Berdasarkan perkiraan TKPI kandungan protein tertinggi diperoleh pada F1 dengan nilai 7,33g per takaran saji. Hasil analisis menunjukan bahwa kandungan protein snack bar tertinggi terdapat pada F3 dengan nilai 4,02 g per takaran saji. Hal ini sejalan dengan penelitian Suhartatik (2018) $^{15}$ kandungan protein cenderung meningkat seiring dengan semakin meningkatnya penggunaan tepung beras merah.

\section{KESIMPULAN}

1. Terdapat pengaruh antara rasio tepung beras merah dan kacang hijau terhadap kandungan protein snack bar.

2. Tidak terdapat pengaruh yang signifikan antara rasio tepung beras merah dan kacang hijau terhadap daya terima snack bar pada atribut rasa, aroma dan tekstur. Tetapi terdapat pengaruh yang signifikan terhadap atribut warna.

3. Rasio tepung beras dan kacang hijau yang paling baik terdapat pada F3 dengan perbandingan $60 \mathrm{~g}$ tepung beras merah dan $40 \mathrm{~g}$ kacang hijau pada uji daya terima dan uji kandungan protein.

4. Snack bar F3 memberikan sumbangan protein sebesar $10 \%$ pada anak usia 7-9 tahun, 8\% untuk anak laki-laki usia 10-12 tahun dan 7,3\% untuk anak perempuan 10-12 tahun, berdasarkan angka kecukupan gizi.
5. Anjuran konsumsi snack bar dalam sehari agar memenuhi sumbangan AKG pada anak usia sekolah sebanyak 3 takaran saji.

\section{DAFTAR PUSTAKA}

1. Almatsier, S. Prinsip Dasar Ilmu Gizi, edisi ke-6. Jakarta: Gramedia Pustaka Utama, 2006.

2. Kementerian Kesehatan RI. Laporan Hasil Riset Kesehatan Dasar (Riskesdas) tahun 2018. Jakarta: Badan Penelitian dan Pengembangan Kesehatan Kemenkes RI. 2018.

3. Wardoyo, Hanum Aprilia; Mahmudiono, Trias. Hubungan Makan Pagi Dan Tingkat Konsumsi Zat Gizi Dengan Daya Konsentrasi Siswa Sekolah Dasar. Media Gizi Indonesia, 2013, 9.1: 49-53.

4. Primasoni, Nawan. Manfaat Protein Untuk Mendukung Aktifitas Olahraga, Pertumbuhan, Dan Perkembangan Anak Usia Dini. Universitas Negeri Yogyakarta: Fakultas Ilmu Olahraga, 2012.

5. Harisina, Alzha Adila, Et Al. Mutu Organoleptik, Nilai Gizi (Protein, Kalsium, Serat) Dan Nilai Ekonomi Flakes Subtitusi Buah Sukun Dan Kacang Hijau Sebagai Alternatif Pmt Anak Sekolah. 2016. Phd Thesis. Universitas Airlangga.

6. Christian, Melia. Pengolahan Banana Bars Dengan Inulin Sebagai Alternatif Pangan Darurat. Skripsi. Bogor: Fakultas Teknologi Pertanian Institut Pertanian Bogor, 2011.

7. Chandra, Feriana. Formulasi Snack Bar Tinggi Serat Berbasis Tepung Sorgum (Sorghum Bicolor L), Tepung Maizena, Dan Tepung Ampas Tahu. Skripsi. Jurusan Ilmu Dan Teknologi Pangan, Fakultas Teknologi Pertanian, Institut Pertanian Bogor, Bogor, 2010.

8. Kementrian Kesehatan RI. Hasil Pemantauan Status Gizi 2016.Direktorat Gizi Masyarakat. Direktorat Jenderal Kesehatan Masyarakat Kementrian Kesehatan RI 2018. 
9. Rahardjo, Lisda Juniarsy; Bahar, Asrul; Adi, Annis Catur. Pengaruh Kombinasi Kacang Kedelai (Glycine Max) Dan Kacang Tunggak (Vigna Unguiculata (L) Walp.) Yang Diperkaya Biji Nangka (Artocarpus Heterophyllus) Terhadap Daya Terima Dan Kadar Protein Snack Bar. Amerta Nutrition, 2019, 3.1: 7177.

10. Alfredo Ade Prasetyo, Ignatius. Karakteristik Fisikokimia Dan Sensori Produk Snackbar Dengan Bahan Dasar Tepung Tempe Koro Pedang Putih (Canavalia Ensiformis L.) Dan Tepung Ubi Jalar Merah (Ipomea Batatas). 2017. Phd Thesis. Fakultas Teknologi Pertanian Universitas Katolik Soegijapranata.

11. Fellows, Peter John. Food Processing Technology: Principles And Practice. Elsevier, 2009.

12. Sarifudin, Achmat, Et Al. Pengaruh Penambahan Telur Pada Kandungan
Proksimat, Karakteristik Aktivitas Air Bebas (Aw) Dan Tekstural Snack Bar Berbasis Pisang (Musa Paradisiaca). Agritech, 2015, 35.1: 18.

13. Purwono, H. R. Kacang hijau. Jakarta: Penebar Swadaya, 2005.

14. Lamid, Astuti; Almasyhuri, Almasyhuri; Sundari, Dian. Pengaruh Proses Pemasakan Terhadap Komposisi Zat Gizi Bahan Pangan Sumber Protein. Media Penelitian Dan Pengembangan Kesehatan, 2015, 25.4: 20747.

15. Suhartatik, Brigitta Rizky Ade Herawati Nanik; Widanti, Yannie Asrie. Cookies Tepung Beras Merah (Oryza Nivara)-Mocaf (Modified Cassava Flour) Dengan Penambahan Bubuk Kayu Manis (Cinnamomun Burmanni). Jitipari (Jurnal Ilmiah Teknologi Dan Industri Pangan Unisri), 2018, 3.1. 